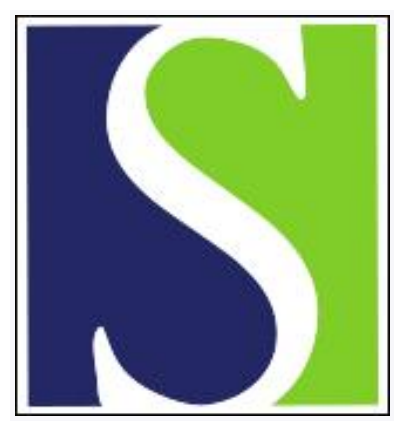

Scand J Work Environ Health 1994;20(2):107-112

https://doi.org/10.5271/sjweh.1424

Issue date: 01 Apr 1994

Lymphocytopenia and occupational exposures among pattern and model makers.

by Demers PA, Schade WJ, Demers RY

Affiliation: Occupational Hygiene Program, University of British Columbia, Vancouver, Canada.

This article in PubMed: www.ncbi.nlm.nih.gov/pubmed/8079131

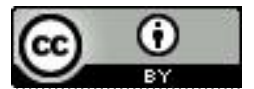




\title{
Lymphocytopenia and occupational exposures among pattern and model makers
}

\author{
by Paul A Demers, PhD, ${ }^{1}$ William J Schade, MD, ${ }^{2}$ Raymond Y Demers, $\mathrm{MD}^{2,3}$
}

\begin{abstract}
DEMERS PA, SCHADE WJ, DEMERS RY. Lymphocytopenia and occupational exposures among pattern and model makers. Scand J Work Environ Health 1994;20:107-12.

OrJecrives - The study was performed to examine the relationship between a high prevalence of lymphocytopenia observed during a cancer screening program for pattern and model makers, who produce industrial prototypes and patterns, and 15 occupational exposures.

MEthods - The cases $(N=83)$ were workers with lymphocyte counts of less than 1000 , while the referents $(\mathrm{N}=529)$ had counts of 1500 or higher. Exposures at the current workplace, and at up to 19 previous pattern and model shops, were assessed with the use of a questionnaire.

Results - Elevated risks were associated with exposure to epoxy resins [odds ratio (OR) 1.94, 95\% confidence interval $(95 \% \mathrm{CI}) 1.02-3.70)$ and plastic dusts (OR 2.60, 95\% CI 1.19-5.68) after adjustment for age and smoking status. No clear associations were found with duration of exposure or percentage of time potentially exposed. Although the results were based upon small numbers, epoxy resins and wood dust displayed the most consistent relationships in an analysis of changes in lymphocyte count and exposure status over time.

Conclusions - While firm conclusions cannot be drawn, the strongest associations observed in this study were for exposure to epoxy resins.
\end{abstract}

KEY TERMS - cancer, epoxy resins, immune system, lymphocytes, occupational disease.

Pattern and model makers are highly skilled workers responsible for producing prototypes and patterns for mass-production industries, such as the automobile manufacturing industry. Members of this trade are potentially exposed to a wide variety of substances, including natural and laminated woods, various metals, plastics, resins, and solvents (1). Several studies conducted in the 1980s found pattern and model makers to be at elevated risk for colon and rectal cancer (2-4). In response, a cancer screening program was initiated in 1981 for members of the Pattern and Model Makers League of North America (PML), the union representing these workers outside of large industries. The cancer screening was primarily directed towards detecting colon and rectal cancer, but other standard screening procedures, including blood chemistries and complete blood counts, were also performed.

In an analysis of the cancer screening results for 1981 and 1982, a relatively high proportion $(26.2 \%)$ of participants was observed to have low lymphocyte counts $\left(<1500 \cdot \mathrm{mm}^{-3}\right)(5)$. By contrast, only $5.6 \%$ of a comparable occupational group had values of

1 Occupational Hygiene Program, University of British Columbia, Vancouver, Canada.

2 Center for Occupational Health, Wayne State University, Detroit, Michigan, the United States.

3 Division of Epidemiology, Michigan Cancer Foundation, Detroit, Michigan, the United States.

Reprint requests to: Dr RY Demers, MD, Center for Occupational Health, 4201 St Antoine, Suite 4-F, Detroit, MI 48201, USA.
$<1500 \cdot \mathrm{mm}^{-3}$. In an analysis of a subgroup of participants in the 1988 screening, a relationship was found between low counts of T cells and natural killer cells and employment as a pattern or model maker (6). In addition, a relationship between low total lymphocyte, T4, and natural killer cell counts and the presence of colon and rectal polyps was observed. In order to explore whether these low lymphocyte counts were associated with occupational exposures, a case-referent study among pattern and model makers who participated in the screening program was performed.

\section{Subjects and methods}

The subjects were selected from among participants in the 1985 cancer screening program in Detroit, Michigan, and the surrounding region. All members of the PML associations representing workers in southeastern Michigan were eligible to attend the screening program. The participants (all men) were employed at "job shops," which primarily produce patterns and models for automobile manufacturers and other mass-production industries.

Blood counts were performed with a standard instrument generating a three-part differential count, the Coulter "S plus IV." Cases were defined as persons with lymphocyte counts of $<1000 \cdot \mathrm{mm}^{-3}$. The referents were screening participants with counts of $\geq 1500 \cdot \mathrm{mm}^{-3}$. Persons with intermediate counts were excluded from the case-referent analysis. Because of 
the relatively short half-life of lymphocytes and their ability to regenerate quickly, only screening participants who were currently employed were included in the analysis (7).

Prior to the screening, all of the participants were asked to complete a work history questionnaire designed to collect a detailed history of exposure to 15 different substances commonly encountered in the trade, including two substances identified by trade-

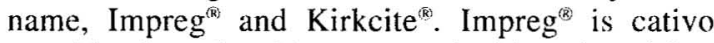
wood laminated and impregnated with a phenol-formaldehyde resin, such that the product is $30 \%$ resin, while Kirkcite ${ }^{(2)}$ is a metal alloy composed primarily of zinc $(90 \%)$ with smaller amounts of nickel, titanium, copper, and iron. Pattern and model making is frequently a life-long profession, and it is common for workers at "job shops" to change employers as frequently as every one or two years, either because of downturns in the industry resulting in layoffs or because of an advance in pay scale. Thus the workers were queried as to the percentage of time they worked with each of the substances at their current shop and up to the 19 pattern and model making shops at which they had been previously employed. Screening participants who did not fill out a work history questionnaire were excluded from the analysis.

Analyses were conducted using logistic regression to compare the history of exposure among the cases and referents. The mean age of the cases was 45 years and $20 \%$ were current smokers, while the mean age of the referents was 39 years and $43 \%$ were current smokers. Smoking was negatively associated with lymphocytopenia [odds ratio (OR) $0.34,95 \%$ confidence interval $(95 \% \mathrm{CI}) 0.19-0.60 \mathrm{~J}$, while age was somewhat positively associated (OR 2.29 for $30-39$ years, OR 1.90 for $40-49$ years, and OR 3.83 for $\geq 50$ years relative to those $<30$ years of age). Thus a decision was made to adjust for age $(<30,30-39,40-49, \geq 50)$ and current smoking status in all of the analyses.

Table 1. Prevalence of exposure among the pattern and model makers according to case and referent status in respect to lymphocytopenia.

\begin{tabular}{|c|c|c|c|c|c|c|c|c|}
\hline \multirow{3}{*}{ Exposure } & \multicolumn{4}{|c|}{ Currently exposed } & \multicolumn{4}{|c|}{ Ever exposed } \\
\hline & \multicolumn{2}{|c|}{ Cases } & \multicolumn{2}{|c|}{ Referents } & \multicolumn{2}{|c|}{ Cases } & \multicolumn{2}{|c|}{ Referent } \\
\hline & $\mathrm{N}$ & $\%$ & $N$ & $\%$ & $\mathrm{~N}$ & $\%$ & $\mathrm{~N}$ & $\%$ \\
\hline Hard wood & 53 & 64 & 348 & 66 & 63 & 76 & 388 & 73 \\
\hline Soft wood & 66 & 80 & 383 & 72 & 69 & 83 & 428 & 81 \\
\hline Impreg & 51 & 61 & 322 & 61 & 62 & 75 & 380 & 72 \\
\hline Kirkcite " & 10 & 12 & 71 & 13 & 23 & 28 & 147 & 28 \\
\hline Other metals & 43 & 52 & 249 & 47 & 60 & 72 & 345 & 65 \\
\hline Solvents & 62 & 75 & 398 & 75 & 68 & 82 & 432 & 82 \\
\hline Cutting oils & 31 & 37 & 209 & 40 & 45 & 54 & 296 & 56 \\
\hline Welding fumes & 21 & 25 & 138 & 26 & 39 & 47 & 237 & 45 \\
\hline Epoxy resins & 60 & 72 & 352 & 67 & 70 & 84 & 404 & 76 \\
\hline Polyesters & 44 & 53 & 269 & 51 & 53 & 64 & 334 & 63 \\
\hline Other plastics & 47 & 57 & 300 & 57 & 59 & 71 & 358 & 68 \\
\hline Plastic dusts & 63 & 76 & 376 & 71 & 75 & 90 & 426 & 81 \\
\hline Fiber glass & 46 & 55 & 283 & 53 & 61 & 73 & 372 & 70 \\
\hline Asbestos & 4 & 5 & 27 & 5 & 12 & 14 & 60 & 11 \\
\hline Plasters & 25 & 30 & 150 & 28 & 44 & 53 & 276 & 52 \\
\hline
\end{tabular}

An alternate analysis was also performed to examine whether changes in exposure status over time led to a drop in lymphocyte counts. For this analysis, the subjects consisted of all PML screening participants who attended both the 1985 and 19811982 screening programs and were currently employed at the time of the 1985 screening. Our a priori hypothesis was that those workers not exposed to the potential causal agent or agents at either screening or during the time between should have little change in their lymphocyte counts, while those exposed at the first screening, but who ceased to be exposed prior to the second, should have an increase in their lymphocyte counts. On the other hand, decreases in lymphocyte count might be expected among those workers who began exposure between the two screenings or who were exposed at both.

\section{Results}

A total of 864 men attended the 1985 screening and 858 had total lymphocyte counts performed. Of the $858,86(10 \%)$ had counts of $\leq 1000 \cdot \mathrm{mm}^{-3}, 550$ (64\%) had counts of $\geq 1500 \cdot \mathrm{mm}^{3}$, and $222(26 \%)$ had intermediate counts. Thus there were 86 potential "cases" and 550 potential "referents." Two cases and 10 referents were not currently employed at the time of the screening, and one case and 11 referents did not provide an adequate work history for the analysis. After exclusions, 83 cases and 529 referents were available for the analysis.

No association was found with number of years employed as a pattern or model maker (OR 1.00, 95\% Cl 0.96-1.03) after adjustment for age and smoking status. As part of the occupational history, screening participants were queried as to the main material with which they worked. No association was found for primarily working with woods (OR 0.97 , $95 \%$ CI 0.59-1.59), metals (OR 0.97, 95\% CI $0.54-1.73$ ), or plastics (OR $1.07,95 \%$ CI $0.61-$ 1.86). Table 1 lists the 15 specific exposures queried in the questionnaire with the percentage of cases and referents currently exposed and ever exposed.

Table 2 lists the odds ratios and $95 \%$ confidence intervals associated with the 15 exposures. The first column presents the odds ratios for exposure at the time of the screening with the reference category consisting of those not currently exposed. The second column of table 2 presents the results for currently exposed versus never exposed. The risks associated with exposure to epoxies and plastic dusts were the most highly elevated. The risks associated with exposure to soft woods, metals other than Kirkcite $^{(k)}$, and fiber glass appeared to be somewhat elevated; however, the confidence limits were wide and included one. The second column of table 2 yields results which are almost identical to those obtained using an ever versus never categorization of exposure. For example, the odds ratio associated with ever 
having worked with epoxy resins was $1.95(95 \% \mathrm{CI}$ 1.03-3.71), while the corresponding odds ratio for plastic dusts was 2.81 (95\% CI 1.29-6.12).

In table 3 the data from column 2 of table 2 are stratified by the percentage of time spent working with the material. No exposure appeared to have a clear association with this surrogate measure of dose that could not be ruled out as due to chance. Asbestos was excluded from the table because no cases or referents reported having used it more than $50 \%$ of the time. The odds ratios associated with exposure to both epoxy resins and plastic dusts were elevated for both those who had reported using the substances for less than $50 \%$ of the time and for those who reported using the substances more than $50 \%$ of the time. Table 4 lists the odds ratios by category of duration of exposure relative to no history of exposure. As in table 3, no exposure appeared to have a clear association with this additional surrogate measure of dose.

Table 2. Odds ratios (OR) and $95 \%$ confidence intervals (95\% $\mathrm{Cl}$ ) for lymphocytopenia among the pattern and model makers by exposure at the time of screening.

\begin{tabular}{|c|c|c|c|c|}
\hline \multirow[t]{2}{*}{ Exposure } & \multicolumn{2}{|c|}{$\begin{array}{l}\text { Currently exposed } \\
\text { versus not } \\
\text { currently exposed }\end{array}$} & \multicolumn{2}{|c|}{$\begin{array}{l}\text { Currently exposed } \\
\text { versus never } \\
\text { exposed }\end{array}$} \\
\hline & $\mathrm{OR}^{\mathrm{a}}$ & $95 \% \mathrm{Cl}$ & $\mathrm{OR}^{\mathrm{a}}$ & $95 \% \mathrm{Cl}$ \\
\hline Hard wood & 0.97 & $0.59-1.59$ & 1.11 & $0.64-1.95$ \\
\hline Soft wood & 1.62 & $0.91-2.89$ & 1.38 & $0.73-2.58$ \\
\hline Impreg: & 0.98 & $0.60-1.60$ & 1.10 & $0.63-1.92$ \\
\hline Kirkcite : & 0.93 & $0.45-1.93$ & 0.94 & $0.45-1.96$ \\
\hline Other metals & 1.41 & $0.87-2.28$ & 1.59 & $0.91-2.77$ \\
\hline Solvents & 1.18 & $0.68-2.06$ & 1.27 & $0.68-2.39$ \\
\hline Cutting oils & 1.12 & $0.68-1.86$ & 1.15 & $0.67-1.97$ \\
\hline Welding fumes & 1.03 & $0.60-1.79$ & 1.13 & $0.64-2.00$ \\
\hline Epoxy resins & 1.54 & $0.91-2.62$ & 1.94 & $1.02-3.70$ \\
\hline Polyesters & 1.14 & $0.71-1.83$ & 1.09 & $0.65-1.81$ \\
\hline Other plastics & 1.15 & $0.71-1.88$ & 1.31 & $0.76-2.25$ \\
\hline Plastic dusts & 1.54 & $0.88-2.68$ & 2.60 & $1.19-5.68$ \\
\hline Fiber glass & 1.26 & $0.78-2.04$ & 1.38 & $0.79-2.41$ \\
\hline Asbestos & 1.10 & $0.36-3.32$ & 1.18 & $0.39-3.61$ \\
\hline Plasters & 1.14 & $0.68-1.93$ & 1.08 & $0.62-1.89$ \\
\hline
\end{tabular}

a Adjusted for age group and cigarette smoking status.
A total of 405 participants in the 1985 screening also attended the 1981-1982 cancer screening. This group consisted of 48 cases, 253 referents, and 104 men with lymphocyte counts between 100 and $1499 \cdot \mathrm{mm}^{-3}$ in 1985 . The mean lymphocyte count at the earlier screening for persons defined as cases in the current study was $1677 \cdot \mathrm{mm}^{-3}$, while their mean for the 1985 screening was $798 \cdot \mathrm{mm}^{-3}$. The mean value for the intermediate group also dropped between the two screenings, from 1660 to $1286 \cdot \mathrm{mm}^{-3}$, while the mean value for the referents rose slightly during the same time period (from 2098 to $2241 \cdot \mathrm{mm}^{-3}$ ). Only exposure to soft wood and epoxy resins (table 5) displayed relationships with lymphocyte counts in the directions hypothesized a priori. A small number of participants, four in the case of both the soft wood and epoxy resin analyses, who had multiple changes in exposure status were excluded from the exposure-specific analyses. The analyses of all other exposures displayed either

Table 3. Odds ratios (OR) and $95 \%$ confidence intervals ( $95 \%$ $\mathrm{Cl}$ ) for lymphocytopenia among the pattern and model makers by exposure at the time of screening and the percentage of time exposed.

\begin{tabular}{|c|c|c|c|c|}
\hline \multirow{2}{*}{ Exposure } & \multicolumn{2}{|c|}{ Less than $50 \%$} & \multicolumn{2}{|c|}{ Greater than $50 \%$} \\
\hline & $\mathrm{OR}^{\mathrm{a}}$ & $95 \% \mathrm{Cl}$ & $\mathrm{OR}^{\mathrm{a}}$ & $95 \% \mathrm{Cl}$ \\
\hline Hard wood & 1.16 & $0.64-2.08$ & 0.99 & $0.45-2.16$ \\
\hline Soft wood & 1.61 & $0.84-3.07$ & 0.89 & $0.40-1.98$ \\
\hline Impreg. & 1.20 & $0.64-2.24$ & 0.99 & $0.52-1.90$ \\
\hline Kirkcite & 0.78 & $0.33-1.82$ & 1.80 & $0.47-6.98$ \\
\hline Other metals & 1.53 & $0.78-3.00$ & 1.63 & $0.87-3.07$ \\
\hline Solvents & 1.36 & $0.72-2.59$ & 0.94 & $0.40-2.20$ \\
\hline Cutting oils & 1.19 & $0.68-2.08$ & 0.90 & $0.29-2.80$ \\
\hline Welding fumes & 1.22 & $0.68-2.19$ & 0.44 & $0.06-3.52$ \\
\hline Epoxy resins & 1.98 & $1.01-3.88$ & 1.84 & $0.85-3.99$ \\
\hline Polyesters & 0.95 & $0.55-1.66$ & 1.61 & $0.77-3.36$ \\
\hline Other plastics & 1.24 & $0.70-2.22$ & 1.48 & $0.71-3.06$ \\
\hline Plastic dusts & 2.78 & $1.25-6.18$ & 2.23 & $0.92-5.44$ \\
\hline Fiber glass & 1.62 & $0.90-2.91$ & 0.92 & $0.42-2.03$ \\
\hline Plasters & 1.22 & $0.69-2.15$ & 0.30 & $0.04-2.33$ \\
\hline
\end{tabular}

a Relative to never exposed and adjusted for age group and cigarette smoking status.

Table 4. Odds ratios (OR) and $95 \%$ confidence intervals $(95 \% \mathrm{Cl})$ for lymphocytopenia among the pattern and model makers by category of duration of exposure.

\begin{tabular}{|c|c|c|c|c|c|c|}
\hline \multirow{2}{*}{ Exposure } & \multicolumn{2}{|c|}{$0.1-4.9$ years } & \multicolumn{2}{|c|}{$5.0-9.9$ years } & \multicolumn{2}{|c|}{$\geq 10$ years } \\
\hline & $\mathrm{OR}^{\mathrm{a}}$ & $95 \% \mathrm{Cl}$ & $\mathrm{OR}^{\mathrm{a}}$ & $95 \% \mathrm{Cl}$ & $\mathrm{OR}^{\mathrm{a}}$ & $95 \% \mathrm{Cl}$ \\
\hline Hard wood & 1.47 & $0.70-3.07$ & 1.06 & $0.45-2.47$ & 1.08 & $0.58-2.01$ \\
\hline Soft wood & 1.29 & $0.58-2.88$ & 0.66 & $0.25-1.80$ & 1.30 & $0.67-2.56$ \\
\hline Impreg & 1.56 & $0.79-3.09$ & 1.05 & $0.48-2.30$ & 0.94 & $0.49-1.80$ \\
\hline Kirkcite & 1.00 & $0.48-2.11$ & 1.39 & $0.57-3.37$ & 0.72 & $0.28-1.83$ \\
\hline Other metals & 1.15 & $0.53-2.50$ & 2.11 & $1.01-4.43$ & 1.60 & $0.87-2.92$ \\
\hline Solvents & 1.22 & $0.51-2.92$ & 1.51 & $0.66-3.46$ & 1.29 & $0.66-2.50$ \\
\hline Cutting oils & 1.20 & $0.57-2.51$ & 1.81 & $0.85-3.87$ & 0.93 & $0.50-1.72$ \\
\hline Welding fumes & 0.79 & $0.37-1.69$ & 1.49 & $0.66-3.35$ & 1.56 & $0.85-2.87$ \\
\hline Epoxy resins & 1.88 & $0.82-4.28$ & 2.14 & $0.95-4.85$ & 1.92 & $0.96-3.84$ \\
\hline Polyesters & 1.14 & $0.56-2.31$ & 0.90 & $0.39-2.04$ & 1.03 & $0.58-1.84$ \\
\hline Other plastics & 1.37 & $0.69-2.72$ & 1.46 & $0.65-3.29$ & 1.47 & $0.80-2.70$ \\
\hline Plastic dusts & 2.83 & $1.14-7.04$ & 3.63 & $1.41-9.39$ & 2.60 & $1.15-5.89$ \\
\hline Fiber glass & 1.31 & $0.64-2.67$ & 2.36 & $1.13-4.92$ & 1.17 & $0.62-2.21$ \\
\hline Asbestos & 1.42 & $0.51-3.90$ & 1.11 & $0.24-5.13$ & 2.18 & $0.71-6.75$ \\
\hline Plasters & 0.50 & $0.22-1.15$ & 0.99 & $0.45-2.21$ & 1.36 & $0.77-2.43$ \\
\hline
\end{tabular}

a Relative to never exposed and adjusted for age group and cigarette smoking status. 
Table 5. Changes in the lymphocyte counts of the pattern and model makers between the 1981-1982 screening and the 1985 screening in relation to exposure status.

\begin{tabular}{|c|c|c|c|c|c|c|c|}
\hline \multirow[b]{2}{*}{ Exposure } & \multicolumn{3}{|c|}{ Time of screening } & \multicolumn{4}{|c|}{ Lymphocyte count } \\
\hline & $\begin{array}{r}1981- \\
1982\end{array}$ & 1985 & $\mathrm{~N}$ & $\begin{array}{c}1981- \\
1982\end{array}$ & 1985 & Change & SE \\
\hline \multicolumn{8}{|l|}{ Soft wood } \\
\hline & $\begin{array}{l}\text { No } \\
\text { Yes } \\
\text { No } \\
\text { Yes }\end{array}$ & $\begin{array}{l}\text { No } \\
\text { No } \\
\text { Yes } \\
\text { Yes }\end{array}$ & $\begin{array}{r}95 \\
6 \\
22 \\
278\end{array}$ & $\begin{array}{l}1864 \\
1948 \\
1885 \\
1974\end{array}$ & $\begin{array}{l}1775 \\
2318 \\
1593 \\
1857\end{array}$ & $\begin{array}{r}-88 \\
370 \\
-292 \\
-116\end{array}$ & $\begin{array}{r}76 \\
145 \\
196 \\
43\end{array}$ \\
\hline \multicolumn{8}{|c|}{ Epoxy resins } \\
\hline & $\begin{array}{l}\text { No } \\
\text { Yes } \\
\text { No } \\
\text { Yes }\end{array}$ & $\begin{array}{l}\text { No } \\
\text { No } \\
\text { Yes } \\
\text { Yes }\end{array}$ & $\begin{array}{r}119 \\
16 \\
14 \\
252\end{array}$ & $\begin{array}{l}1821 \\
1758 \\
1751 \\
2021\end{array}$ & $\begin{array}{l}1817 \\
1869 \\
1683 \\
1839\end{array}$ & $\begin{array}{r}-4 \\
112 \\
-67 \\
-182\end{array}$ & $\begin{array}{r}70 \\
176 \\
211 \\
45\end{array}$ \\
\hline \multicolumn{8}{|c|}{ Plastic dusts } \\
\hline & $\begin{array}{l}\text { No } \\
\text { Yes } \\
\text { No } \\
\text { Yes }\end{array}$ & $\begin{array}{l}\text { No } \\
\text { No } \\
\text { Yes } \\
\text { Yes }\end{array}$ & $\begin{array}{r}111 \\
13 \\
18 \\
260\end{array}$ & $\begin{array}{l}1833 \\
2112 \\
1937 \\
1978\end{array}$ & $\begin{array}{l}1859 \\
1670 \\
1738 \\
1832\end{array}$ & $\begin{array}{r}26 \\
-442 \\
-199 \\
-146\end{array}$ & $\begin{array}{r}76 \\
161 \\
+27 \\
45\end{array}$ \\
\hline Total & . & · & 405 & 1935 & 1825 & -111 & 54 \\
\hline
\end{tabular}

a decrease in lymphocyte count after the cessation of exposure or an increase after the beginning of exposure. Plastic dusts are included in table 5 as an example. Those who ceased exposure to plastic dusts had a mean decrease of $442 \cdot \mathrm{mm}^{-3}$ in their lymphocyte count, whereas an increase in lymphocyte count would have been predicted. The differences between those who had been exposed at the time of both screenings and those who had not been exposed at either reached statistical significance $(\mathrm{P}<0.05)$ for both epoxy resins and plastic dusts. The difference between those who had been exposed to plastic dusts at the time of the first screening but had ceased exposure by the time of the second screening and those who had not been exposed at either was also statistically significant. None of the other differences were statistically significant; however, many of the comparisons were based upon small numbers.

\section{Discussion}

The most consistent association with lymphocytopenia observed in this study was with exposure to epoxy resins. Lymphocytopenia was associated with both a current and past use of epoxy resins, and decreases and increases of lymphocyte counts correlated in the predicted direction with sequential exposure versus nonexposure to these substances. The fact that exposure at the time of both screenings was associated with a larger decrease in lymphocyte count than exposure only at the time of the latter screening would suggest that, if a true relationship exists, chronic exposure may be important. However, no consistent associations were found with duration of exposure or percentage of time spent working with the material in the current job, and the analyses of changes over time were sometimes based upon small numbers.
The results for other exposures considered in this analysis were less consistent. Although current exposure to plastic dusts was associated with lymphocytopenia, the results of the sequential analysis were not in the predicted direction. Likewise, the sequential association with softwood was not substantiated by a clear association with current exposure. In addition, as was the case with epoxy resins, neither exposure showed evidence of a dose-response relationship with lymphocytopenia.

Many substances encountered in the work environment have been found to be immunotoxic (8). However, relatively few studies have been conducted to examine the relationship between work-related exposures and lymphocytopenia. Studies have found a relationship between exposure to asbestos and decreased $T$ helper:suppressor ratios and lower numbers of natural killer cells (9-11). Decreased numbers of lymphocytes have also been associated with occupational exposure to solvents, particularly benzene $(12,13)$. In this analysis neither exposure to asbestos nor exposure to solvents was related to lymphocytopenia. The epoxy compounds typically used in pattern and model making are epichlorohydrin and diglycidyl resorcinol ether, along with hardeners such as diethylenetriamine and triethylenetetramine (1). Exposure to epoxy resins has not been previously associated with lymphocytopenia, although other lymphatic and hematopoietic effects have been observed. An increase in chromosome aberrations in the white blood cells of epoxy-exposed workers has been noted (14), and animal studies have shown glycidyl ether to cause a loss of lymphoid tissue in rats (15).

Although this study was undertaken to explore the relationship between depressed human lymphocyte counts and workplace exposure among pattern and model makers, it was also motivated by concern about the risk of cancer among members of this trade. An excess of colon and rectal cancer has been observed among pattern and model makers in studies of both mortality $(2,3,16)$ and cancer $(3,4,17,18)$ incidence, and an excess of colon and rectal polyps has also been observed (19). Although two recent studies have not observed an excess $(20,21)$, the majority of the evidence indicates that these workers are or were at excess risk of colon and rectal cancer. The cause for the excess risk of cancer observed among these workers has not been identified. Initial suspicion had fallen on wood dust because it is a common exposure and an excess of nasal cancer had been observed in the wood furniture industry (22). However, the one study designed to examine this question did not find an excess of colon cancer associated with wood dust exposure (21).

The observation of a high prevalence of lymphocytopenia in this population has prompted the consideration that a toxic effect on the immune system, as reflected in depressed lymphocyte counts, could predispose the development of colon and rectal cancer. In a previous study of this population, a relationship 
between low total lymphocyte, $\mathrm{T} 4$, and natural killer cell counts and the presence of colon and rectal polyps was observed (6). Another study, based on patient records from the Mayo Clinic, found that, of 510 healthy patients, $6 \%$ had lymphocyte counts of $<1000 \cdot \mathrm{mm}^{-3}$, while, of 227 patients with untreated gastrointestinal malignancies, $22.4 \%$ had counts of $<1000 \cdot \mathrm{mm}^{-3}(22)$. Thus it may be significant to the findings of colon and rectal neoplasia among pattern and model makers that epichlorohydrin has been classified as a probable human carcinogen while diglycidyl resorcinol ether has been classified as a possible human carcinogen (23).

There are some limitations that should be kept in mind when the results of this study are considered. First, the study population consisted of voluntary participants in a cancer screening program. Approximately $35 \%$ of the eligible workers participated in the 1985 screening, while $46 \%$ participated in the 1981-1982 screening (24). The participants in the program have been found to be more likely to be older, to have never smoked, and to have worked with wood. How this history might influence the results of the study is unknown. However, it is important to note that this was a generally healthy working population and it seems unlikely that individual decisions to participate had any relationship with lymphocyte counts. Second, only total lymphocyte count was available for all of the participants. Subset counts, as well as other markers of immune impairment, would have been optimal but, given the expense, were not collected as part of the screening.

Different types of epoxy resins, woods, and plastic dusts may have very different toxic effects. Another limitation of this study was that more specific information regarding exposure was not available. The drop in lymphocyte counts between the two screenings among the persons who subsequently became cases was substantially greater than that observed in relationship to any of the exposures examined. This result might indicate that the true agent responsible for the change in lymphocyte counts was either not measured or poorly measured. The lack of a dose-response relationship in this study may have been due to the fact that both the percentage of time and the duration were poor surrogates for true dose.

In conclusion, epoxy resins formed the exposure most consistent with lymphocytopenia among the pattern and model makers, while weaker evidence was found for exposure to plastic dusts and softwood dust. Because this effect has been observed in a group of workers with an elevated risk of cancer, future investigations will focus on assessing the relationship between these exposures and the risk of colon and rectal cancer.

\section{References}

I. McCammon CS, Robinson C, Waxweiler RJ, Roscoe $R$. Industrial hygiene characterization of automotive wood model shops. Am Ind Hyg Assoc J 1985;46: $343-9$.

2. Robinson C, Waxweiler RJ, McCammon CS. Pattern and model makers, proportionate mortality 1972 1978. Am J Ind Med 1980;1:159—65.

3. Schottenfeld D, Warschauer ME, Zauber AG, Miekle JG, Payne KM, Haas JF. Study of cancer mortality and incidence in wood shop workers of the General Motors Corporation. New York, NY: Memorial SloanKettering Cancer Center, 1980.

4. Swanson GM, Belle SH. Cancer morbidity among wood workers in the US automotive industry. J Occup Med 1982;24:315-9.

5. Bang KM, Laing CA. Lymphocytopenia in high risk cancer population: evidence in automobile pattern makers. Cancer Lett 1986;30:311-4.

6. Robins TG, Weinstein RJ, Demers RY. Lymphocytopenia, T-lymphocyte subsets, and colorectal polyps in automotive pattern and model makers. J Occup Med $1991 ; 33: 510-5$.

7. Al-Sabti K, Lloyd DC, Edwards AA, Stegnar P. A survey of lymphocyte chromosomal damage in Slovenian workers exposed to occupational clastogens. Mutat Res 1992;280:215-23.

8. National Research Council. Biological markers in immunotoxicology. Washington, DC: National Academy Press, 1992.

9. de Shazo RD, Morgan J, Bozelka B, Chapman Y. Natural killer cell activity in asbestos exposed workers, interactive effects of smoking and asbestos exposure. Chest 1988;94:482-5.

10. Jarad NA, Macey M, Uthayakumar S, Newland AC, Rudd RM. Lymphocyte subsets in subjects exposed to asbestos: changes in circulating natural killer cells. $\mathrm{Br}$ J Ind Med 1992;49:811-4.

11. Lew F, Tsang P, Holland JF, Warner N, Selikoff IJ, Bekesi JG. High frequency of immune dysfunction in asbestos workers and in patients with malignant mesothelioma. J Clin Immunol 1986;6:225-33.

12. Denkhaus W, Steldern DV, Botzenhardt U, Konietzko H. Lymphocyte subpopulations in solvent-exposed workers. Int Arch Occup Environ Health 1986;57: $109-15$.

13. Moszczynsky P, Lisiewicz J. Occupational exposure to benzene, toluene, and xylene and the T lymphocyte functions. Haematologia 1984; 17:449-53.

14. Kucerova M, Zurlov VS, Polvkova Z, Ivanova JE. Mutagenic effects of epichlorohydrin: II. analysis of chromosomal aberrations in lymphocytes of persons occupationally exposed to epichlorhydrin. Mutat Res 1977;48:355-60.

15. Kodama JK, Guzman RJ, Dunlap MK, Loquvam CS, Lima R, Hine CH. Some effects of epoxy compounds on the blood. Arch Environ Health $1961 ; 2: 56-67$.

16. Tilley BC, Johnson CC, Schultz LR, Buffler PA, Joseph CLM. Risk of colorectal cancer among automotive pattern and model makers. J Occup Med $1990 ; 32: 541-6$.

17. Hoar SK, Bang KM, Tillett S, Rodriguez M, Cantor $\mathrm{KP}$, Blair A. Screening for colorectal cancer and polyps among pattern makers. J Occup Med 1986;28: $704-8$.

18. Swanson GM, Belle SH, Colon cancer incidence among modelmakers and patternmakers in the automobile manufacturing industry: a continuing dilemma. J Occup Med 1985;27:567-9.

19. Demers RY, Demers P, Hoar SK, Deighton K. Prevalence of colorectal polyps among Michigan pattern and model makers. J Occup Med 1985;27:809-12.

20. Becker N, Kuhn G, Marschall B, Angerer R, Frentzel-Beyme R, Wahrendorf J. Follow-up study among model and pattern makers in an automobile company in the Federal Republic of Germany. J Occup Med 1992;34:552—58. 
21. Roscoe RJ, Steenland K, McCammon CS, Schober SE, Robinson CF, Halperin WE, et al. Colon and stomach mortality among automotive wood model makers. J Occup Med 1992;34:759-70.

22. Zacharski LR, Linman JW. Lymphocytopenia: its causes and significance. Mayo Clin Proc 1971;46: $168-73$.

23. International Agency for Research on Cancer (IARC). Overall evaluation of carcinogenicity: an updating of
IARC monographs, volumes 1-42. Lyon: IARC, 1987.

24. Neale AV, Demers RY, Herman S. Compliance with colorectal cancer screening in a high risk occupational group. J Occup Med 1989;31:1007-12.

Received for publication: 6 April 1993 